\title{
The Effects of Starvation and Surgical Injury on the Plasma Levels of Glucose, Free Fatty Acids, and Neutral Lipids in Newborn Babies Suffering from Various Congenital Anomalies
}

\author{
M. C. ELPHICK ${ }^{(14)}$ AND A. W. WILKINSON \\ Department of Paediatric Surgery. Institute of Child Health, 30 Guilford Street, London WCI, England
}

\section{Summary}

Blood glucose, plasma free fatty acids (FFA), cholesterol, phospholipids, and triglycerides were measured in blood obtained by heel prick from 32 neonatal surgical patients suffering from various congenital malformations which prevented an adequate intake of milk. The result of almost complete starvation for up to 7 days was investigated and the effects of a surgical operation were studied in 12 of the babies. All the babies weighed more than $2 \mathbf{~ k g}$ at birth.

A surgical operation caused a rise in blood glucose concentration but a variable change in plasma concentration of FFA. Blood glucose returned to normal within 8 to $12 \mathrm{hr}$. The plasma concentrations of cholesterol and phospholipids did not change except in two babies in whom the concentration of both fell. Four to $24 \mathrm{hr}$ after operation the plasma triglyceride level fell by an average of 25\% but later rose.

During starvation for 7 days, the blood glucose concentration was maintained within normal limits. Plasma FFA concentration normally rose during the first 2 days of life and was very high between days 3 and 5. Plasma triglyceride, cholesterol, phospholipids, and total esterified fatty acids also increased after birth. The results suggest that during starvation in the neonate there is rapid mobilisation of fat from adipose tissue stores and a reduction in the peripheral utilisation of glucose. There was no evidence to suggest any impairment of fat mobilisation or metabolism even after starvation for 7 days. After surgical injury, these changes were accentuated because the rate of utilisation of fat was greater than that of mobilisation.

\section{Speculation}

Babies of normal birthweight may be more able to cope with starvation and surgical injury than is generally realised.

Measurements of the respiratory quotient of newborn babies indicate that perhaps as much as $80 \%$ of the energy requirement is derived from fat (2). Although carbohydrate is the main source of energy in the fetus, soon after birth and before feeding is started there is a rapid fall in glycogen reserves (27), and in the blood glucose concentration (5) and an increase of plasma free fatty acids (FFA) and ketone bodies (18, 19).

Surgical operations in the neonate are nearly always accompanied by starvation which may be prolonged especially if the gastrointestinal tract is involved (32). In the human baby, depot fat accounts for 10 to $15 \%$ of body weight (31), and it may be the main source of energy during starvation soon after birth (12).
Many regimes are used for the parenteral nutrition of newborn infants after operation, based on the use of glucose and other carbohydrates, amino acid solutions, and fat emulsions, but there is disagreement as to when and how such solutions should be used. In the present investigation, the plasma concentrations of glucose and lipids were measured in a group of neonatal surgical patients who were selected for study because either they had not been fed or had vomited most of the feeds they had been given. The purpose of this investigation was to determine how well the neonate can maintain normal plasma concentrations of glucose and lipids during starvation and whether these estimations could be used as a basis for assessing the baby's nutritional status. In addition, we wished to investigate the metabolic effects of injury in the neonate because little work has been done on this important aspect of neonatal care.

\section{PATIENTS AND METHODS}

The newly born babies who were chosen for this investigation (Table 1) had been admitted as emergencies for the surgical treatment of various congential anomalies. In such patients, blood is invariably taken for grouping and cross-matching of blood for transfusion at operation and for other purposes associated with their clinical management, and blood was obtained for our estimations at the same time with their parents' consent. Patients are operated on only when compatible blood is available. Most babies had not been fed at all, and those who had had vomited or regurgitated most if not all, of the feeds. This information was obtained from the case notes on admission to hospital. In addition a clinical assessment of the babies' nutritional condition was made from, among other things, the appearance of stools and the state of the bowels at operation. In a few of the babies, electrolytes had been infused intravenously, but none had been given any glucose solution before or during operation. At the time these observations were made, anaesthesia was induced and maintained with a nitrous oxide-oxygen mixture with small quantities of halothane and the intermittent injection of suxamethonium; this and other drugs used by the anaesthetists were diluted with sterile water and injected directly into a needle inserted into a scalp vein; continuous intravenous infusions were not used. At times during the course of the operations, these babies were only lightly anaesthetised. and this no doubt led to the release of endogenous catecholamines which would mobilise FFA and glucose.

The duration of starvation before operation was related to delay or errors in diagnosis. After operation, our objective was always to feed the babies in one way or another within $24 \mathrm{hr}$, either 
Table 1. Details of the 32 babies in whom blood lipids were analyzed

\begin{tabular}{|c|c|c|c|c|c|}
\hline Case & $\begin{array}{l}\text { Birth } \\
\text { weight } \\
(\mathrm{kg})\end{array}$ & Disease & Milk & $\begin{array}{l}\text { Age at blood } \\
\text { sampling } \\
(\mathrm{hr})\end{array}$ & Outcome \\
\hline 1 & 3.18 & Myelomeningocele & None & $14,18^{1}, 26^{1}$ & Survived \\
\hline 2 & 2.64 & Anorectal atresia & None & $18,211^{\prime} 30,,^{\prime} 43^{\prime}$ & Survived \\
\hline 3 & 2.52 & Ileal atresia & Some absorbed & $25,28,^{\prime} 37^{\prime} 49^{\prime}$ & Died, aged $3 \mathrm{wk}$ \\
\hline 4 & 2.16 & Duodenal atresia & $\begin{array}{l}\text { Some into } \\
\text { stomach }\end{array}$ & $88,92,,^{\prime} 111^{\prime}$ & Died, aged 5 wk \\
\hline 5 & 2.95 & Meconium ileus & Some absorbed & 92. $122, .^{\prime} 134^{\prime}$ & Survived \\
\hline 6 & 2.87 & Hiatus hernia & None & 106 & Survived \\
\hline 7 & 3.69 & Myelomeningocele & None & 162 & Survived \\
\hline 8 & 3.46 & Teratoid twin & None & 24 & Died, aged 8 yr \\
\hline 9 & 2.72 & $\begin{array}{l}\text { Diaphragmatic hernia, hy- } \\
\text { poplastic L lung, bilat- } \\
\text { eral pneumothorax }\end{array}$ & None & 7 & Died, aged $48 \mathrm{hr}$ \\
\hline 10 & 2.75 & Anorectal atresia & None & $57^{1}$ & Survived \\
\hline 11 & 2.16 & $\begin{array}{l}\text { Exomphalos, duodenal } \\
\text { atresia }\end{array}$ & Little absorbed & $91^{\prime}$ & Died, aged 36 days \\
\hline 12 & 3.07 & Meconium ileus & Some absorbed & 44 & Survived \\
\hline 13 & 2.68 & Hiatus hernia & None & 107 & Survived \\
\hline 14 & 4.02 & Myelomeningocele & None & $28^{1}$ & Survived \\
\hline 15 & 2.72 & Anorectal atresia & None & 24 & Survived \\
\hline 16 & 3.43 & Anorectal atresia & None & 30 & Survived \\
\hline 17 & 2.74 & Exomphalos & None & 24 & Survived \\
\hline 18 & 2.61 & Anorectal atresia & None & $9,23,28,29^{1}$ & Survived \\
\hline 19 & 2.67 & Oesophageal atresia & None & $\begin{array}{c}71,74,77,{ }^{\prime} 81,{ }^{\prime} 92,{ }^{\prime} 95,{ }^{\prime} \\
100,{ }^{1} 106^{\prime}\end{array}$ & Survived \\
\hline 20 & 3.48 & $\begin{array}{l}\text { Swallowed endotracheal } \\
\text { tube, respiratory distress }\end{array}$ & None & $32^{\prime} 35^{\prime} 42^{\prime}$ & Survived \\
\hline 21 & 3.41 & Hiatus hernia & $\begin{array}{l}\text { Some taken but } \\
\text { vomited }\end{array}$ & 86,95 & Survived \\
\hline 22 & 3.37 & Myelomeningocele & None & $4,8,11,,^{\prime} 18,{ }^{\prime} 22^{\prime}$ & Survived \\
\hline 23 & 2.36 & Oesophageal atresia & None & $\begin{array}{l}40,45,{ }^{\prime} 48,{ }^{\prime} 55,{ }^{\prime} 59,{ }^{\prime} \\
65,,^{\prime} 72,{ }^{\prime} 82^{\prime}\end{array}$ & Died, aged 2 yr \\
\hline 24 & 2.09 & $\begin{array}{l}\text { Duodenal atresia } 37 \mathrm{wk} \\
\text { gestation }\end{array}$ & Some taken & $24,29,30,^{\prime} 36,,^{\prime} 48^{\prime}$ & Survived \\
\hline 25 & 3.21 & Anorectal atresia & None & $31^{1}$ & Survived \\
\hline 26 & 3.29 & Intestinal obstruction & Some absorbed & $24,25,,^{\prime} 29,,^{\prime} 45^{\prime}$ & Survived \\
\hline 27 & 2.45 & Intestinal obstruction & Some absorbed & $89^{1}$ & Survived \\
\hline 28 & 2.75 & $\begin{array}{l}\text { Pseudointestinal obstruc- } \\
\text { tion }\end{array}$ & Some absorbed & 52.72 & Survived \\
\hline 29 & 3.35 & $\begin{array}{l}\text { Spina bifida hydrocepha- } \\
\text { lus }\end{array}$ & None & $9,17^{1}$ & Survived \\
\hline 30 & 3.29 & Meconium obstruction & Some absorbed & $79.91^{1}$ & Died, aged $13 \mathrm{wk}$ \\
\hline 31 & 3.27 & Low ileal atresia & Some absorbed & $144,146,{ }^{\prime} 162,{ }^{\prime} 168^{\prime}$ & Survived \\
\hline 32 & 2.73 & Myelomeningocele & None & 23 & Survived \\
\hline
\end{tabular}

normally by mouth or by transanastomotic tube placed at operation for oesophageal or duodenal atresia. When feeds were delayed beyond $24 \mathrm{hr}$, this was only because this was judged to be necessary on clinical grounds and was in no way related to our studies. The initial feeds were usually $5 \mathrm{ml}$ of $5 \%$ glucose solution every hr, which were changed to expressed breast milk or modified cow's milk after 5 or $6 \mathrm{hr}$. However, no samples for our study were taken once the initial feeds were started, and starvation was never prolonged for the purpose of this investigation. Blood for our analyses was taken only when it was being withdrawn for other reasons directly connected with the clinical management and treatment of the baby.

The babies were divided into eight groups according to age at the time of blood sampling (Table 2). All the babies were nursed in incubators maintained at about $30^{\circ} \mathrm{C}$. Relative humidity was not measured. Because of the absence of control groups of normally fed babies, the results have been compared with previously published values where the same analytical methods or methods based on the same chemical reactions had been used.

After pricking the warmed heel, blood was collected into heparinised capillary tubes. A total of not more than $0.4 \mathrm{ml}$ of blood
Table 2. The numbers of babies studied and blood samples taken'

\begin{tabular}{ccc} 
Age at blood sampling $(\mathrm{hr})$ & $\begin{array}{c}\text { No. of babies } \\
\text { in group }\end{array}$ & $\begin{array}{c}\text { No. of blood } \\
\text { samples taken }\end{array}$ \\
\hline Cord blood & 11 & 11 \\
$4-12$ & 4 & 6 \\
$12-24$ & 10 & 14 \\
$24-36$ & 10 & 16 \\
$36-48$ & 8 & 10 \\
$48-72$ & 6 & 10 \\
$72-96$ & 8 & 15 \\
$96-120$ & 4 & 7 \\
$120-168$ & 3 & 7 \\
\hline
\end{tabular}

1 The babies were grouped according to age. Some babies are included in more than one group. depending on how long they were included in the study.

was taken at any one time. For glucose estimation, whole blood was added to test tubes by the bedside and immediately subjected to protein precipitation. The remaining blood was centrifuged to collect the plasma. The samples were stored at $-20^{\circ} \mathrm{C}$ until 
analysed. Blood glucose was estimated using glucose oxidase (11) and plasma FFA was measured according to the method of Novák (17). The other plasma lipids were extracted and analysed for total cholesterol, triglyceride fatty acids, and phospholipids as previously described (18). For comparison, eleven samples of umbilical cord venous blood, obtained after normal delivery at term, were analysed in the same way.

\section{RESULTS}

\section{THE EFFECT OF OPERATION}

In 14 of the 32 babies listed in Table 1, blood was sampled before and after operation. The plasma FFA concentrations in individual babies are shown in Figure 1; the differences before and up to $12 \mathrm{hr}$ after operation were not significant. In contrast, the blood glucose concentrations were increased immediately after operation (Fig. 2) and declined towards the pre-operative levels within 8 to 12 hr. Figure 3 shows changes in the plasma concentrations of phospholipids, cholesterol, and triglycerides, respectively, after operation. Sufficient blood for these estimations was obtained in eight of the 12 babies mentioned above (cases 2, 3, 4, $18,19,22,23$, and 24). For reasons of clarity, the results have been plotted as changes from the pre-operative levels because their initial values varied according to the age of the infants. concentrations in the older babies being higher.

There was no significant change in either the plasma total cholesterol or phospholipid concentrations after surgical injury. In two babies, however, there was a large fall in both occurring between 4 and $12 \mathrm{hr}$ after return from the theatre, but there was no clinical explanation for this. In individual babies, the changes in plasma cholesterol concentrations were most often associated with similar changes in phospholipid levels. The pre-operative cholesterol concentration was $119 \pm 11 \mathrm{mg} \%$ (mean \pm S.E., range 78 to $183 \mathrm{mg} \%$ ). The pre-operation plasma phospholipid level was $167 \pm 8 \mathrm{mg} \%$ (mean \pm S.E.: range, 140 to $207 \mathrm{mg} \%$ ).

The plasma triglyceride concentrations are shown in Figure 3c. The mean level found before operation was $1.6 \pm 0.3 \mathrm{mM}$ (mean \pm S.E.; range, 1.0 to $2.9 \mathrm{mM}$ ). After operation, the concentration fell in every baby studied: the trough occurred after 8 to $24 \mathrm{hr}$ with slight subsequent rises. The drop represented a change in concentration of about $0.3 \mathrm{mM}$, and in some cases where the values were initially low, this represented a fall of up to $50 \%$.

\section{THE EFFECT OF STARVATION}

The plasma FFA levels in the 32 neonatal patients as measured during the first week of life, together with previously published data for normal fed babies, are shown in Table 3 with our determinations on 11 samples of cord blood. There is a postnatal rise in serum FFA in both normal and starving babies. A second

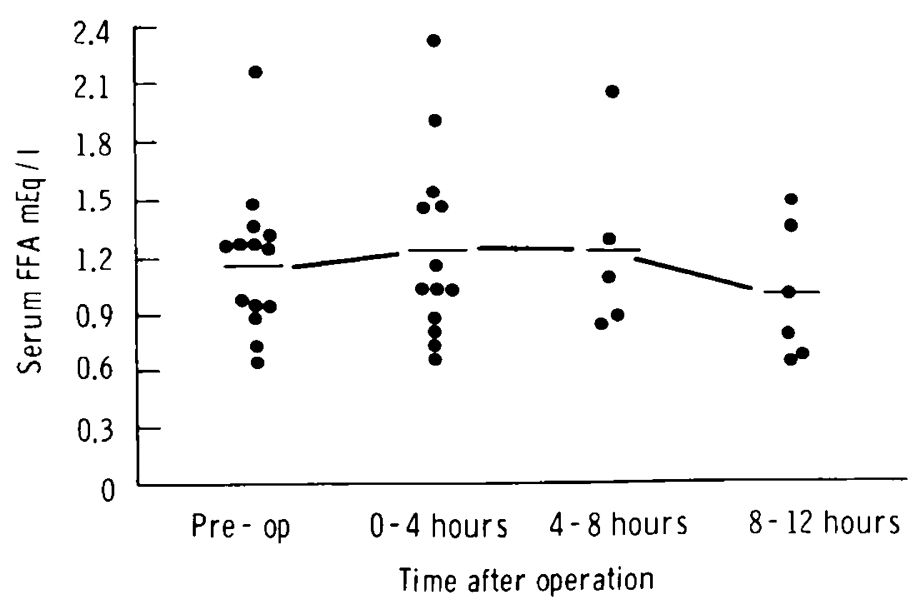

Fig. 1. Serum concentrations of FFA in 14 of the starving babies listed in Table 1 before and after operation.

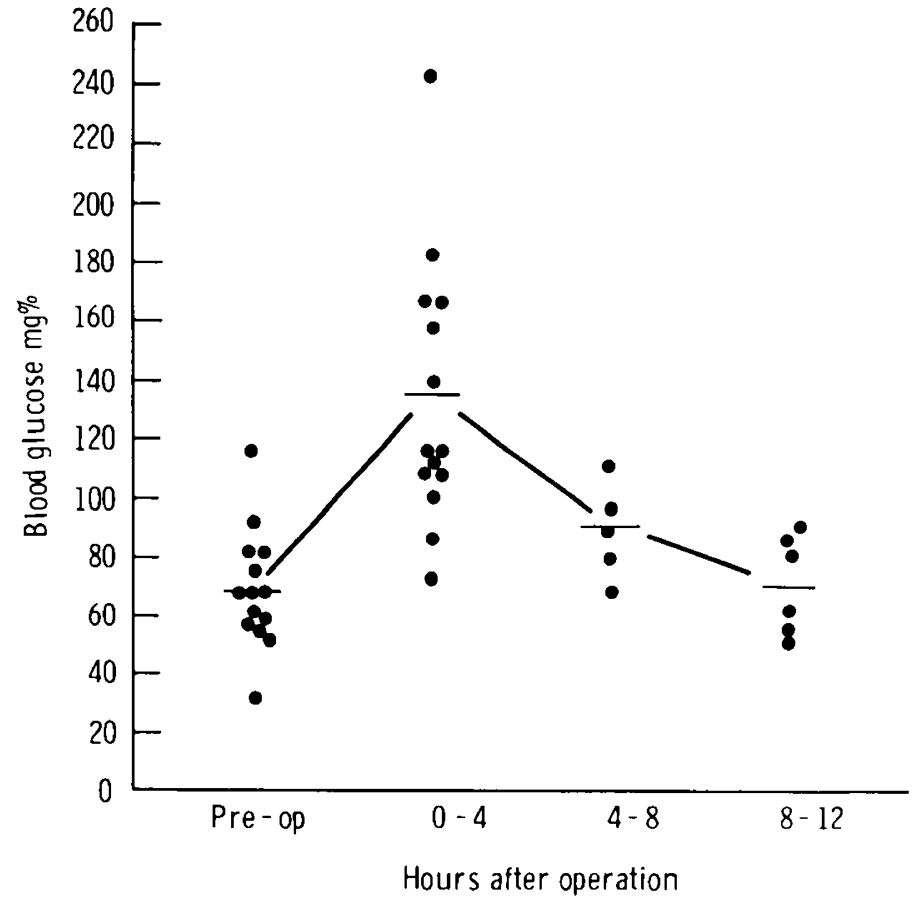

Fig. 2. Changes in the blood glucose level in the same babies shown in Figure 1 . The rise in blood glucose up to $4 \mathrm{hr}$ postoperatively was highly significant $(P<0.001)$. After 4 to $8 \mathrm{hr}$, the concentration was still raised $(P<0.05)$, but returned to its initial level 8 to $12 \mathrm{hr}$ after the operation.

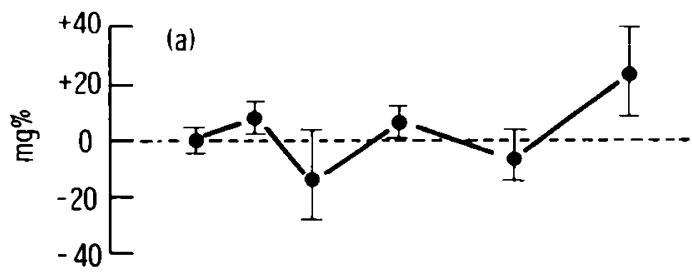

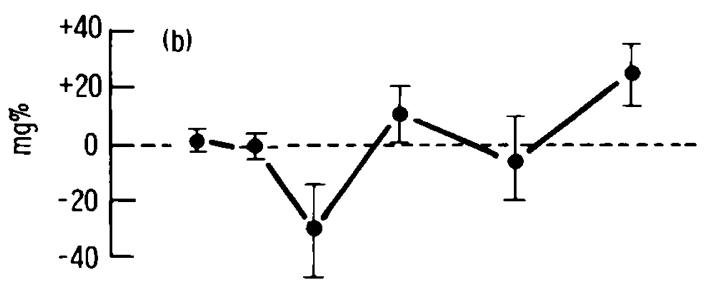

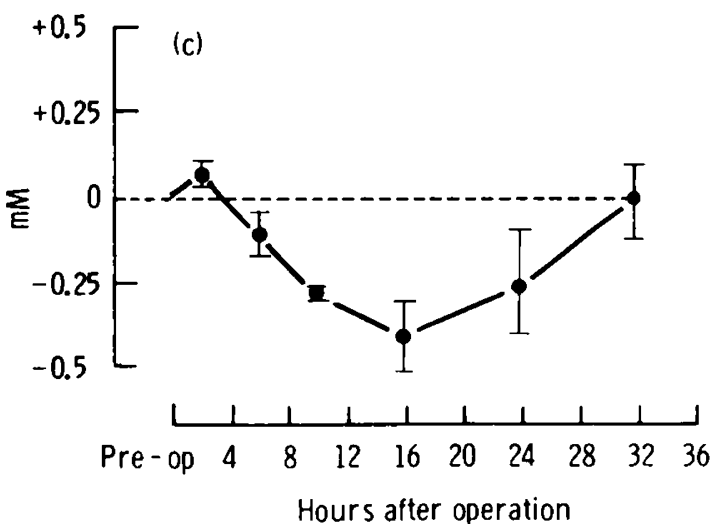

Fig. 3. Changes in the plasma concentrations of total cholesterol $(a)$. phospholipids $(b)$, and triglycerides $(c)$ in eight starving babies after operation. Changes were significant for triglycerides only. Sixteen hr after operation, the levels were lower $(P<0.001)$ compared with before surgery. Points, mean value: hars, \pm S.E. 
Table 3. Blood glucose and plasma FFA concentrations during the first wk of life ${ }^{1}$

\begin{tabular}{|c|c|c|c|c|}
\hline \multirow[b]{2}{*}{ Age $(h r)$} & \multicolumn{2}{|c|}{$\begin{array}{l}\text { Blood glucose } \\
(\mathrm{mg} / 100 \mathrm{ml})\end{array}$} & \multicolumn{2}{|c|}{$\begin{array}{c}\text { Plasma FFA } \\
\text { (mEq/liter) }\end{array}$} \\
\hline & Normal (6) & Starved & Normal (18) & Starved \\
\hline Cord blood & $86 \pm 8^{2}$ & $85 \pm 3$ & $0.25 \pm 0.07$ & $0.27 \pm 0.03^{3}$ \\
\hline $0-12$ & $53 \pm 2$ & $64 \pm 6$ & $0.93 \pm 0.09$ & $0.91 \pm 0.18$ \\
\hline $12-24$ & $56 \pm 2$ & $68 \pm 4$ & $1.23 \pm 0.10$ & $1.17 \pm 0.08^{3}$ \\
\hline $24-36$ & $58 \pm 2$ & $72 \pm 6$ & $1.06 \pm 0.08$ & $0.93 \pm 0.08$ \\
\hline $36-48$ & $57 \pm 3$ & $75 \pm 6$ & $1.12 \pm 0.09$ & $0.83 \pm 0.09$ \\
\hline $48-72$ & $70 \pm 4$ & $72 \pm 6$ & $1.00 \pm 0.10$ & $0.90 \pm 0.08^{3}$ \\
\hline $72-96$ & $69 \pm 1$ & $75 \pm 7$ & & $1.58 \pm 0.17^{3}$ \\
\hline $96-120$ & $69 \pm 4$ & $64 \pm 8$ & & $1.20 \pm 0.13$ \\
\hline $120-168$ & $71 \pm 2$ & $96 \pm 23$ & $0.91 \pm 0.08$ & $0.98 \pm 0.13$ \\
\hline
\end{tabular}

1 The number of babies in each group and number of blood samples taken are shown in Table 2 . The range of glucose values in the starving babies was from 30 to $116 \mathrm{mg} / 100 \mathrm{ml}$. Blood glucose levels determined up to $12 \mathrm{hr}$ after operation are excluded.

2 Mean \pm S.E.

${ }^{3}$ Difference between means for starving babies. $P<0.001$ (Student's $t$ test).

Table 4. Changes with age in plasma lipids in normal and starved babies ${ }^{1}$

\begin{tabular}{|c|c|c|c|c|c|c|c|c|}
\hline \multirow[b]{2}{*}{ Age (hr) } & \multicolumn{2}{|c|}{$\begin{array}{l}\text { Triglycerides } \\
\text { (mM) }\end{array}$} & \multicolumn{2}{|c|}{$\begin{array}{l}\text { Esterified fatty acids } \\
\quad(\mathrm{mEq} / \text { liter })\end{array}$} & \multicolumn{2}{|c|}{$\begin{array}{l}\text { Phospholipids } \\
\text { (mg/100 ml) }\end{array}$} & \multicolumn{2}{|c|}{$\begin{array}{l}\text { Total cholesterol } \\
(\mathrm{mg} / 100 \mathrm{ml})\end{array}$} \\
\hline & Normal (18) & Starved & Normal (18) & Starved & $\begin{array}{l}\text { Normal } \\
(15,19)\end{array}$ & Starved & $\begin{array}{l}\text { Normal } \\
(15,19)\end{array}$ & Starved \\
\hline Cord blood & $0.41 \pm 0.04^{2}$ & $0.72 \pm 0.05$ & $5.7 \pm 0.9$ & $6.7 \pm 0.5$ & $65 \pm 3$ & $88 \pm 8$ & $96 \pm 4$ & $83 \pm 9$ \\
\hline $0-12$ & & $1.23 \pm 0.45$ & $5.5 \pm 0.4$ & $8.4 \pm 1.1$ & & $93 \pm 10$ & & $150 \pm 12$ \\
\hline $12-24$ & $0.71 \pm 0.12$ & $1.13 \pm 0.23$ & & $7.7 \pm 0.7$ & $85 \pm 6$ & $91 \pm 7$ & $115 \pm 9$ & $118 \pm 7$ \\
\hline $24-36$ & & $1.46 \pm 0.20$ & $8.8 \pm 0.9$ & $9.2 \pm 0.8$ & & $109 \pm 11$ & & $158 \pm 8$ \\
\hline $36-48$ & & $1.33 \pm 0.10$ & $10.4 \pm 1.3$ & $9.3 \pm 0.6$ & & $108 \pm 7$ & & $170 \pm 11$ \\
\hline $48-72$ & $1.18 \pm 0.10$ & $1.20 \pm 0.19$ & & $8.9 \pm 0.9$ & $102 \pm 7$ & $119 \pm 9$ & $156 \pm 6$ & $171 \pm 17$ \\
\hline $72-96$ & & $2.16 \pm 0.22$ & & $11.8 \pm 0.8$ & & $124 \pm 13$ & & $180 \pm 12$ \\
\hline $96-120$ & $1.18 \pm 0.09$ & $1.83 \pm 0.16$ & & $11.5 \pm 0.8$ & $126 \pm 9$ & $126 \pm 18$ & $162 \pm 7$ & $180 \pm 11$ \\
\hline $120-168$ & $1.08 \pm 0.09$ & $2.87 \pm 0.66$ & $12.2 \pm 1.2$ & $12.5 \pm 1.7$ & $120 \pm 10$ & $92 \pm 5$ & $152 \pm 6$ & $179 \pm 10$ \\
\hline
\end{tabular}

' For number of babies and number of observations in each group, see Table 2.

${ }^{2}$ Mean \pm S.E

peak was observed in the latter group between 72 and $96 \mathrm{hr}$ of age. The blood glucose results for the same infants are also shown in Table 3. Glucose determinations made up to $12 \mathrm{hr}$ postoperatively (Fig. 2) have been excluded. The results are compared with normal levels and with our values for cord blood. Blood glucose concentrations were maintained within normal limits of 30 to 125 $\mathrm{mg} / 100 \mathrm{ml}^{6}$. The upper limit was exceeded only after a surgical operation (Fig. 2). The blood glucose concentration was below 40 $\mathrm{mg} \%$ in only one baby (case 3 ).

Table 4 shows the results for plasma triglycerides, phospholipids, cholesterol, and total esterified fatty acids. The results are shown with published data and our cord blood values. Plasma total cholesterol and phospholipids increased after birth in both fed and starving babies, although the increase in the latter group was significant only for the phospholipids. Plasma triglycerides and total esterified fatty acids likewise increased with age, the increase in the latter being significant after $72 \mathrm{hr}$.

\section{DISCUSSION}

In this investigation, the effects of the two different stresses of surgical operation and starvation were studied. Because the one is superimposed upon the other, it is impossible to separate their effects. The main problem in interpreting the results is in estimating the effects of operation on the pattern of changes observed during starvation. A second difficulty is related to the nutritional state of the babies. Some with low intestinal obstruction had obviously taken and absorbed a certain, but unknown, amount of milk, and although these patients were carefully selected for study only after a clinical assessment of the baby's food intake, this fact should be borne in mind when interpreting the results.

\section{THE EFFECT OF OPERATION}

The plasma FFA level showed a variable response to surgical injury (Fig. 1). Naftalin (16) and Stoner (28) concluded that injury causes an increase in FFA turnover. Pinter (20), in a study similar to our own, found a slight increase in plasma FFA during operation followed by a further increase which was greatest in babies in whom the operation did not involve the alimentary tract. A rise in plasma FFA also occurs after laparotomy in unfed newborn rabbits (8). The weight of evidence suggests that there is an increased FFA turnover in the newly born human or rabbit after surgical injury, but a firm conclusion cannot be made until FFA turnover has been directly measured.

It is well known that injury causes a rise in the blood glucose concentration in adult man, coupled with a reduction in glucose tolerance (25). We also found an increase in the blood glucose concentration after operation (Fig. 2), but the concentration returned to normal within $12 \mathrm{hr}$ in contrast to adult surgical patients where it may remain high for several days (1). Our results are very like those reported by Pinter (20). An increase in olood glucose might be caused by increased production or decreased utilisation of glucose or a combination of the two. Glucose utilisation has been measured with the intravenous glucose tolerance test in neonatal patients after operation and was found to be low (9). It seems likely that in these patients the type of anaesthesia which was used, with the likelihood of endogenous catecholamine 
release, was an important factor in the rise in blood glucose concentration soon after operation. Similar results have been obtained in newborn rabbits (7) and in puppies (22).

It is generally agreed that plasma FFA originates mainly from adipose tissue. Endogenous plasma triglyceride is produced by the liver from circulating FFA and is released into the circulation in the form of lipoproteins. The very low density lipoproteins are rich in triglyceride, which by hydrolysis can provide tissue with fatty acids for energy and for storage. Most of the babies in this study were unfed so that the circulating lipids were probably of endogenous origin.

Our results demonstrate that surgical injury has little effect on circulating cholesterol and phospholipids (with the exception of two patients) but does reduce triglyceride concentrations. The plasma neutral lipids in adult man after a surgical operation have been studied by Man et al. (14), Cholette et al. (4), and Wadström (30), all of whom found that the plasma triglycerides fell shortly after operation. The reduction in the triglyceride concentrations of babies after operation may indicate accelerated stripping of fatty acids from endogenous lipoprotein for energy production. This requires further investigation, especially in view of the use of fat emulsion for intravenous feeding after operation. It is unlikely that hepatic production of lipoprotein was disturbed because there was little change in the concentrations of cholesterol and phospholipids.

\section{STARVATION}

Starvation for up to a week did not result in hypoglycaemia in babies of normal birth weight (Table 3 ). Thus, except in the case of premature or underweight babies, the administration of intravenous glucose to prevent "starvation hypoglycaemia" is unnecessary.

As well as representing another source of energy, FFA have a glucose sparing action (24). it is tempting, therefore, to relate the maintenance of a normal blood sugar during starvation with the availability of body fat. In the newborn pig where fat reserves are equivalent to only $1 \%$ of body weight (10), hypoglycaemia develops quickly during starvation, and this is associated with a fall in plasma FFA levels (29). When the piglets have been fed, however, and have built up their fat reserves, starvation results in a prompt elevation of blood FFA, and circulating glucose is kept within normal ranges. In starved newborn rabbits, the clearance rate of injected glucose was found to follow a reciprocal pattern with the plasma FFA level $(7,8)$. The human neonate at term contains much more fat than the piglet.

The serum FFA levels were high in the babies of this investigation, especially between the third and fourth days of life (Table 3 ). We observed a similar postnatal rise in concentration to that found in normal babies. The lower levels found in the normal babies after the first 2 days may be due to feeding. Even after 7 days of almost complete starvation, there was no evidence to suggest an impaired mobilisation of fatty acids from adipose tissue. We did not find any relationship between blood glucose and serum FFA concentrations in our patients. Pinter $(20,21)$ also failed to find such a relationship in babies studied during and immediately after operation and over the next few days.

From metabolic balance data, Hughes et al. (12) calculated that only about $8 \%$ of body protein $(29 \mathrm{~g})$ was catabolised when a $3 \mathrm{~kg}$ neonate was starved for 12 days, yet $30 \%$ of the baby's fat was used up. Because of this low conversion of protein, the ability to reduce peripheral glucose utilisation would be of advantage to the starving neonate, but whether or not high FFA turnover can result in reduced peripheral glucose uptake remains to be confirmed. Glycerol released from adipose tissue during lipolysis could be a source of blood glucose.

It has been known for many years that the lipid concentration of mixed cord blood is lower than that of maternal blood (3). Lipid concentration in the venous blood of babies rises during the first week of life (26). If glucose alone is fed to newborn infants for the first 3 to 5 days of life, then the total fatty acid, cholesterol, and phospholipid content of plasma rise more slowly than when breast milk is given $(13,23)$. This is probably the consequence of decreased FFA mobilisation from adipose tissue because glucose infusions reduce the postnatal rise in plasma FFA from which endogenous lipoprotein triglyceride is produced (18). However, the possibility that exogenous fat from milk is present in plasma from fed babies cannot be excluded.

Our results indicate that the plasma cholesterol, phospholipids, triglycerides, and total esterified fatty acids increase after birth in unfed babies in a similar way, but perhaps not so markedly, as in normal babies (Table 4). One has to bear in mind that on the one hand surgical injury resulted in a temporary lowering of the total fatty acid level (Fig. $3 c$ ) resulting in an underestimation, while on the other hand, there is some doubt as to the nutritional state of some of the babies, and we may have detected lipids of exogenous origin in the plasma.

In conclusion, we did not have any evidence to suggest that endogenous sources of energy were not supplying a sufficient amount of calories to cover the requirements of babies of normal birth weight during starvation caused by congenital anomalies and during and after the surgical operations required to correct them.

\section{REFERENCES AND NOTES}

I. Akamatsu, T., Ohba, M., Narahara, N., Kodaira, S., Maruta, M., Mimura, T., and Uekusa $M$.: Effect of abdominal surgery on glucose tolerance. plasma levels of insulin and glycogenic amino acids. Keio J. Med., 19: 103 (1970).

2. Benedict, F. G., and Talbot F. B.: The physiology of the newborn infant Character and amount of the katabolism. Carnegie Inst. Pub. No. 233. Washington (1915).

3. Boyd. E. M.. and Wilson, K. M.: Exchange of lipids in umbilical circulation at birth. J. Clin. Invest., I4: 7 (1935).

4. Cholette, C.. Payne, M. A. Cornell, G. N., and Beal, J. M.: Serum lipid levels following operation. S. Forum, 5: 424 (1954).

5. Cornblath, M., Ganzon, A. F., Nicolopoulos, D., Baens, G. S., Hollander, R. J.. Gordon. M. H., and Gordon. H. H.: Studies of carbohydrate metabolism in the newborn infant. III. Some factors influencing the capillary blood sugar and the response to glucagon during the first hours of life. Pediatrics, 27: 378 (1961).

6. Cornblath. M., and Schwartz, R.: Disorders of carbohydrate metabolism in infancy. (W. B. Saunders Co., Philadelphia, 1966).

7. Elphick, M. C.: The effect of starvation and injury on the utilisation of glucose in newborn rabbits. Biol. Neonate, 17: 399 (1971).

8. Elphick. M. C.: Seum lipids in newborn rabbits with reference to starvation and injury. Biol. Neonate, 17: 410 (1971).

9. Elphick M. C.. and Wilkinson A. W.: Glucose intolerance in newborn infants undergoing surgery for alimentary tract anomalies. Lancet, 539 (1968).

0. Gentz, J. Bengtsson, G., Hakkarainen. J., Hellstrom, R., and Persson, B.: Metabolic effects of starvation during the neonatal period in the piglet. Am. J. Physiol., 218: 662 (1970).

11. Huggett, A. St. G., and Nixon, D. A.: Use of glucose oxidase, peroxidase and $o$ dianisidine in determination of blood and urinary glucose. Lancet, $2: 368$ (1957).

12. Hughes, E. A., Stevens, L. H., and Wilkinson, A. W.: Some aspects of starvation in the newborn baby. Arch. Dis. Child., 39: 598 (1964).

13. Kohn, R.. Novak, M.. Melichar, V.. Havlova, M., and Vinslova, N.: Changes in neonatal cholesteraemia and serum phospholipods in modified nutrition. Cesk. Pediatr., 16: 979 (1961).

14. Man, E. B., Bettcher, P. G., Cameron, C. M., and Peters, J. P.: Plasma-amino acid nitrogen and serum lipids of surgical patients. J. Clin. Invest.. 25: 701 (1946).

15. Melichar, V., Novak, M., Hahn, P., Koldovsky, O., and Zeman, L.: Changes in the blood levels of lipid metabolites and glucose following a fatty meal in infants. Acta Paediatr. Scand.. 51: 481 (1962).

16. Naftalin, L.: Blood ketone and plasma NEFA levels in the immediate postoperative period. Clin. Chim. Acta, 7: 614 (1962).

17. Novak, M.: Colorimetric ultramicro method for the determination of free fatty acids. J. Lipid Res., 6: 431 (1965).

18. Novák. M., Melichar, V., Hahn, P., and Koldovsky, O.: Levels of lipids in the blood of newborn infants and the effect of glucose administration. Physiol. Bohemoslov., 10: 488 (1961).

19. Persson, B., and Gentz. J.: The pattern of blood lipids, glycerol and ketone bodies during the neonatal period, infancy and childhood. Acta Paediatr. Scand.. 55: 353 (1966).

20. Pinter, A.: The metabolic effects of anaesthesia and surgery in the newborn infant. Changes in the blood levels of glucose. plasma free fatty acids, $x$-amino nitrogen, plasma amino-acid ratio and lactate in the neonate. $Z$. Kinderchir. Grenzgeb., I2: 149 (1973).

21. Pinter. A.: Metabolic changes in newborn infants following surgical operations. 
I. Blood levels of glucose, plasma free fatty acids $\alpha$-amino nitrogen, plasma amino acid ratio and urea nitrogen. Acta Paediatr. Acad. Sci. Hung., 16: 171 (1975).

22. Pinter. A.. and Schafer. J.: Metabolic effects of anaesthesia and surgery in the newborn: blood glucose. plasma free fatty acids, free amino acid and blood lactate level in newborn puppies. Acta Paediatr. Acad. Sci. Hung., 14: 85 (1973).

23. Rafstedt. S.: Studies on serum lipids and lipoproteins in infancy and childhood. Acta Paediatr. Scand. Suppl., 102: 1 (1955).

24. Randle, P. J.. Garland. P. B., Hales. C. N., and Newsholme, E. A.: The glucose fatty acid cycle, its role in insulin sensitivity and the metabolic disturbances of diabetes mellitus. Lancet. 1: 785 (1963).

25. Ross. H.. Welbourn, T. A.. Johnston. 1. D. A.. and Wright. A. D.: Effect of abdominal operation on glucose tolearance and serum levels of insulin, growth hormone and hydrocortisone. Lancet, 2: 563 (1966).

26. Senn. M. J. E., and McNamara. H.: Lipids of blood plasma in neonatal period. Am. J. Dis. Child., 53: 445 (1937).

27. Shelley. H. J.: Glycogen reserves and their changes at birth and in anoxia. $\mathrm{Br}$. Med. Bull. 17: 137 (1961).
28. Stoner. H. B.: Studies on the mechanism of shock: the effect of limb ischaemia on the non-esterified fatty acids of rat plasma. Br. J. Exp. Pathol., 43: 556 (1962).

29. Swiatek, K. R., Kipnis, D. M., Mason, G., Chao, K-L., and Cornblath, M.: Starvation hypoglycaemia in newborn pigs. Am. J. Physiol., 2/4: 400 (1968).

30. Wadstrom. L. B.: Changes in the concentration of unesterified fatty acids glycerides and phospholipids in human plasma following operation. Acta Chir. Scand., 116: 167 (1958/1959).

31. Widdowson. E. M.. and Spray. C. M.: Chemical development in utero. Arch. Dis. Child., 26: 205 (1951).

32. Wilkinson, A. W.: The starving newborn baby. Proc. Nutr. Soc.. 28: 6I (1969).

33. The present address of M. C. Elphick is: Department of Child Health, Medical School, Queen's Medical Centre. Nottingham NG7 2UH. England.

34. Requests for reprints should be addressed to: Dr. M. C. Elphick, Department of Child Health, Medical School, Queen's Medical Centre, Nottingham, NG7 2UH. England.

35. Received for publication April 2, 1979.

36. Accepted for publication July 22, 1980. 